\title{
Adsorption studies on the removal of coloring agent phenol red from wastewater using waste materials as adsorbents
}

\author{
Alok Mittal $^{\text {a }}$, Dipika Kaur ${ }^{\mathrm{a}}$, Arti Malviya ${ }^{\mathrm{a}}$, Jyoti Mittal ${ }^{\mathrm{a}}$, V.K. Gupta ${ }^{\mathrm{b}, \mathrm{c}, *}$ \\ a Department of Applied Chemistry, Maulana Azad National Institute of Technology, Bhopal 462 007, India \\ ${ }^{\mathrm{b}}$ Department of Chemistry, Indian Institute of Technology Roorkee, Roorkee 247777 , India \\ ${ }^{\mathrm{c}}$ Department of Chemistry, College of Science, P.O. Box 5057, King Fahad University of Petroleum and Mines, Dhahran 31261, Saudi Arabia
}

\section{A R T I C L E I N F O}

\section{Article history:}

Received 3 April 2009

Accepted 12 May 2009

Available online 19 May 2009

\section{Keywords:}

Adsorption

Bottom ash

Deoiled soya

Phenol red

Dye

\begin{abstract}
A B S T R A C T
Bottom ash, a waste of thermal power plants, and deoiled soya, an agricultural waste material, were employed for successful removal and recovery of hazardous phenol red dye from wastewaters. The adsorption characteristics and operational parameters were determined by monitoring different parameters such as effect of $\mathrm{pH}$, effect of concentration of the dye, amount of adsorbents, contact time, and temperature. The equilibrium data were analyzed on the basis of various adsorption isotherm models, namely Langmuir, Freundlich, Tempkin, and Dubinin-Radushkevich. The highest monolayer adsorption capacity has been obtained for the phenol red-bottom ash system $\left(2.6 \times 10^{-5} \mathrm{~mol} / \mathrm{g}\right)$ at $50{ }^{\circ} \mathrm{C}$. Different thermodynamic parameters such as free energy, enthalpy, and entropy have been calculated and it was concluded that with the increase in temperature adsorption increases, indicating the endothermic nature of the process for both adsorbent materials. Kinetic parameters were derived from pseudo-firstorder and pseudo-second-order kinetics. Differentiation between particle and film diffusion mechanisms operative in the present study has been carried out. The column regeneration characteristic has been also investigated and recovery percentage greater than $90 \%$ was obtained for both adsorbents by utilizing acidic eluent.
\end{abstract}

(c) 2009 Elsevier Inc. All rights reserved.

\section{Introduction}

Due to rapid industrial development, pollution of water bodies by industries is an issue of major concern. It is estimated that a huge amount of dyes (nearly 20\%) of global production is discharged by textile industries due to incomplete exhaustion of coloring material and washing operations [1]. The effluents generated by these industries are highly visible even at very low concentrations. The disposal of such materials into water bodies not only destructs the esthetic nature but also interferes with the penetration of sunlight, thus affecting the food web existing in water ecosystems [2]. The majority of the dyes dumped into the water bodies by industries are toxic and even carcinogenic to both animals and humans. The problem becomes graver due to the fact that the complex aromatic structures of the dyes render them ineffective in the presence of heat, light, microbes, and even oxidizing agents and degradation of the dyes becomes difficult [3]. Hence these pose a serious threat to human health and water quality, thereby becoming a matter of vital concern. Keeping the essential-

\footnotetext{
* Corresponding author. Address: Department of Chemistry, Indian Institute of Technology Roorkee, 22/2 Niti Nagar, IIT, Roorkee 247 777, India. Fax: +91 1332 273560.

E-mail address: vinodfcy@gmail.com (V.K. Gupta).
}

ity of color removal, concerned industries are required to treat the dye-bearing effluents before dumping them into the water bodies. Thus the scientific community shoulders the responsibility of contributing in the waste treatment by developing effective dyeremoval techniques.

The conventional physicochemical and biological methods such as oxidation and filtration [4-6] are not efficient enough to be utilized for large streams due to their less cost effectiveness and difficult operational conditions [7]. Among the various available water treatment techniques adsorption is the most reliable and efficient technique for decoloration, in which the recovery and recycling of the adsorbent materials can be achieved along with the distinct advantages of nonproduction of any toxic sludge and cost effectiveness. This has encouraged the development of adsorbents that are abundantly available and economical. Nowadays numerous low cost adsorbents are available including products of agricultural origin such as wood dust, sugarcane, fruit peel [8], wheat straw, and apple pomance [9]. Certain other low cost adsorbent materials of industrial origin such as activated slag [10] and bagasse fly ash [11] have also been employed in the recent past. However, still there arises a great need to explore new low cost adsorbent materials with high adsorption capacity.

The present research deals with the applicability of adsorption techniques in the removal of the dye phenol red from wastewaters. 
Phenol red is a highly water-soluble textile dye belonging to the class of triphenylmethane dyes. It exists as a red crystal and is stable in air with solubility of $0.77 \mathrm{~g} / \mathrm{L}$ in water [12]. At $20^{\circ} \mathrm{C}$ the $\mathrm{p} K_{a}$ value has been found to be 8.00 . It is frequently used as a reagent dye for measuring the $\mathrm{pH}$ of water in a range from 6.8 to 8.2 . It changes color from yellow to purple as the $\mathrm{pH}$ goes from 6.7 to 8.2. It is thus widely employed as a pH indicator in cell biology laboratories and for water testing applications.

Toxicity data reveal that phenol red inhibits the growth of renal epithelial cells [13]. Direct or indirect contact with the dye leads to irritation to the eyes, respiratory system, and skin [14]. Phenol red dye is toxic to muscle fibers [15] and its mutagenic effects are also reported [16]. Thus keeping the toxic effects of the dye in view attempts have been made to develop an efficient and cost effective technique for the removal of dye from wastewaters by employing two waste materials, namely bottom ash and deoiled soya. Both adsorbent materials are easily and abundantly available. Bottom ash is obtained from coal-fired stations, whose disposal is always a problem for the industrialists and environmentalists. Deoiled soya is a by-product obtained after complete processing of soyabean. Its use as animal feed is banned nowadays due to formation of antimetabolites which block enzymatic activities in living systems [17]. In the past few years, our laboratory has developed these materials as efficient adsorbents or removal of various dyes from wastewaters [18-24].

\section{Experimental}

\subsection{Materials and methods}

Phenol red, 4'-(3 H-2,1-benzoxathiol-3-ylidene) bis-phenol, S,Sdioxide, having molecular formula $\mathrm{C}_{19} \mathrm{H}_{14} \mathrm{O}_{5} \mathrm{~S}$ and molecular weight 354.38 was obtained from $\mathrm{M} / \mathrm{s}$ Merck. A commonly known synonym for phenol red is phenol sulfonephthalein. The extended conjugation system of the alternate double and single bond in the dye structure gives it an intense color. Some general physicochemical properties of phenol red are presented in Table 1. Dye stock solution was prepared in doubly distilled water. All solutions were prepared by diluting the stock with distilled water.

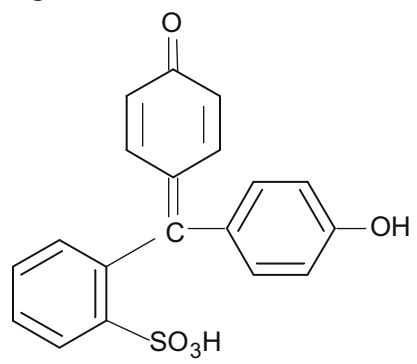

Bottom ash and deoiled soya, the adsorbent materials in the present research work, were obtained from thermal power station (TPS) of M/s Bharat Heavy Electrical Limited (B.H.E.L.), Bhopal (India) and Sanwaria Agro Oils Ltd. Bhopal, respectively. A microprocessor-based pH meter Model HI 8424 (M/s Henna Instruments, Italy) was used for $\mathrm{pH}$ measurements. The absorption studies were carried out using UV-Vis spectrophotometer Model 117 (Systron-

Table 1

Physicochemical properties of phenol red.

\begin{tabular}{ll}
\hline Parameters & Values \\
\hline Class & Triphenylmethane dye \\
Molecular formula & $\mathrm{C}_{19} \mathrm{H}_{14} \mathrm{O}_{5} \mathrm{~S}$ \\
Molecular weight & 354.38 \\
Solubility & Soluble in water $(0.77 \mathrm{~g} / \mathrm{L})$ \\
Absorption maxima & $435 \mathrm{~nm}$ \\
\hline
\end{tabular}

ics, Ahmedabad, India). Philips SEM 501 electron microscope was employed to obtain scanning electron microscopy while a Philips X-ray diffractophotometer was used for X-ray measurements. Quantasorb Model QS-7 surface analyzer was used to calculate the surface of the adsorbent particles. The pore properties and specific gravity of the adsorbents were determined by employing a mercury porosimeter and specific gravity bottles, respectively.

\subsection{Material development}

Both adsorbent materials, bottom ash and deoiled soya, were first washed with distilled water and dried. Then the oxidation of organic impurities was achieved by dipping the materials in $\mathrm{H}_{2} \mathrm{O}_{2}$ solution for about $24 \mathrm{~h}$ followed by washing with double distilled water. The moisture content of the materials was then removed by heating at $100{ }^{\circ} \mathrm{C}$ for about $1 \mathrm{~h}$ in an oven. Deoiled soya was then sieved using various mesh sizes, viz. 36, 100, and 170 BSS mesh, while bottom ash was further heated at $500{ }^{\circ} \mathrm{C}$ for $15 \mathrm{~min}$ for activation followed by the sieving process. The adsorbents were finally stored in a desiccator.

\subsection{Adsorption studies}

Adsorption characteristics were determined with the help of primary analysis. To study the effect of important parameters such as effect of concentration, amount of adsorbent, and $\mathrm{pH}$, batch studies were performed by taking $25 \mathrm{ml}$ of dye solutions in 100$\mathrm{ml}$ volumetric flasks at 30,40 , and $50{ }^{\circ} \mathrm{C}$. A suitable mesh size was chosen for both adsorbent materials (particle size 100 BSS mesh for bottom ash and 36 BSS mesh for deoiled soya) and was added into each flask with intermittent shaking. After $24 \mathrm{~h}$ these solutions were filtered with Whatman filter paper (No. 41) and the amount of the dye adsorbed was analyzed at $\lambda_{\max } 435 \mathrm{~nm}$. The adsorbent dose, concentration, etc. were altered and variation in the amount of dye taken up was analyzed for both adsorbents.

\subsection{Kinetic studies}

Suitable amount of the adsorbents were added to $25 \mathrm{ml}$ of the dye solutions taken in an air-tight 100-ml volumetric flasks and shaking was done periodically. In each case $0.10 \mathrm{~g}$ of either activated bottom ash or activated deoiled soya was taken and studies were performed at different temperatures $\left(30,40\right.$, and $50^{\circ} \mathrm{C}$ ). These solutions were then filtered after a particular time interval and spectrophotometric analysis was carried out for the amount of dye uptake.

\subsection{Column studies}

Column studies were carried out by using two separate glass columns of $30 \mathrm{~cm}$ length and $1 \mathrm{~cm}$ internal diameter, for filling known amounts of bottom ash and deoiled soya, supported on glass wool. To avoid air entrapment, adsorbents were fed into the columns in the form of slurry. Dye solution of $10 \times 10^{-5} \mathrm{M}$ concentration of phenol red was then percolated through the columns at a flow rate of $0.5 \mathrm{ml} /$ min. After complete adsorption the adsorbed dye was eluted using acidic water $(\mathrm{HCl}$ solution of $\mathrm{pH} 2)$, maintaining the flow rate as $0.5 \mathrm{ml} / \mathrm{min}$, for both adsorbent materials. The columns were washed with distilled water after complete elution.

\section{Results and discussion}

\subsection{Characterization of the adsorbents}

The details of the constituents of the adsorbent materials as per chemical analysis are provided in Table 2. Electron microscopy and 
Table 2

Chemical constituents of the adsorbents.

\begin{tabular}{lclll}
\hline Bottom ash & & & Deoiled soya & \\
\cline { 1 - 2 } Constituents & Percentage by weight & & Constituents & Percentage by weight \\
\hline Moisture & 15.0 & & Moisture & 11.0 \\
$\mathrm{SiO}_{2}$ & 45.4 & & $\mathrm{SiO}_{2}$ & 6.0 \\
$\mathrm{Al}_{2} \mathrm{O}_{3}$ & 10.3 & & Fiber & 7.0 \\
$\mathrm{Fe}_{2} \mathrm{O}_{3}$ & 9.7 & $\mathrm{Ca}$ & 0.2 \\
$\mathrm{CaO}$ & 15.3 & & P & 0.7 \\
$\mathrm{MgO}$ & 3.1 & Profat & 48.0 \\
\hline
\end{tabular}

infrared spectroscopy were helpful in providing the absorptive nature and analyzing the two adsorbents. SEM photographs ascertained that the particulates of bottom ash and deoiled soya are almost spherical in shape. Bottom ash gave a sharp absorption band in the region of $3700-3500 \mathrm{~cm}^{-1}$. Laumonite $\left[4\left(\mathrm{CaAl}_{2} \mathrm{Si}_{4}\right.\right.$ $\left.\left.\mathrm{O}_{12} \cdot 4 \mathrm{H}_{2} \mathrm{O}\right)\right]$, amber, mulite $\left.\left[2 \mathrm{Al}_{2} \mathrm{O}_{3} \cdot 2 \mathrm{SiO} \mathrm{O}_{2}\right)\right]$, azurite $\left[\mathrm{Cu}_{3}\left(\mathrm{CO}_{3}\right)_{2}\right.$ $\left.(\mathrm{OH})_{2}\right]$, bavenite $\left.\left[4 \mathrm{Ca}_{4}(\mathrm{BeAl})_{4} \mathrm{Si}_{9} \mathrm{O} \cdot \mathrm{OH}\right)_{29}(\mathrm{OH})_{2}\right]$, and kaolinite $\left[2\left(\mathrm{Al}_{2} \mathrm{Si}_{2} \mathrm{O}_{5}(\mathrm{OH})_{4}\right)\right]$ in bottom ash are indicated by bands at 3467 . $2930,2676,1502,1097$, and $790 \mathrm{~cm}^{-1}$, whereas gorthite [4(FeO-OH $)$, coesite [ $\left.\mathrm{SiO}_{2}\right]$, corundum $\left[2\left(\alpha-\mathrm{Al}_{2} \mathrm{O}_{3}\right)\right]$, and laumonite $\left[4\left(\mathrm{CaAl}_{2} \mathrm{Si}_{4} \mathrm{O}_{12} \cdot 4 \mathrm{H}_{2} \mathrm{O}\right)\right]$, for deoiled soya, were indicated by the bands obtained at 479, 779, 1113 , and $3459 \mathrm{~cm}^{-1}$, respectively. As per DTA curves bottom ash was found to show negligible weight loss even at high temperatures and was also observed to be thermally stable. The X-ray spectrum of the adsorbents showed the presence of gypsum $\left(\mathrm{CaSO}_{4} \cdot 2 \mathrm{H}_{2} \mathrm{O}\right.$, beverite $\left[\mathrm{Pb}(\mathrm{Cu}, \mathrm{Fe}, \mathrm{Al})_{3}\left(\mathrm{SO}_{4}\right)_{2}\right.$ $\left.(\mathrm{OH})_{6}\right]$, alumina $\left(\mathrm{Al}_{2} \mathrm{O}_{3}\right)$, kaolinite $\left[2\left(\mathrm{Al}_{2} \mathrm{Si}_{2} \mathrm{O}_{5}(\mathrm{OH})_{4}\right)\right]$, and borax $\left(\mathrm{Na}_{2} \mathrm{~B}_{4} \mathrm{O}_{7} \cdot 10 \mathrm{H}_{2} \mathrm{O}\right)$. For deoiled soya, the XRD spectrum does not give any major peak(s), which could be due to lack of inorganic substances in the activated deoiled soya.

\subsection{Adsorption studies}

\subsubsection{Effect of $p H$}

$\mathrm{pH}$ is one of the most influencing factors for dye adsorption as it directly affects the dissociative and adsorptive ability of the dye on the adsorbent surface. For phenol red dye the $\mathrm{pH}$ range was chosen as 2-9 for both adsorbents, viz. bottom ash and deoiled soya. The $\mathrm{pH}$ of the test solutions was adjusted by using $\mathrm{HCl}$ and $\mathrm{NaOH}$ solutions. As evident from Fig. 1, with the increase in $\mathrm{pH}$ adsorption was found to decrease till $\mathrm{pH} 5$, but further increase in the $\mathrm{pH}$ value (till $\mathrm{pH} 9$ ) increases the amount adsorbed by both adsorbents.

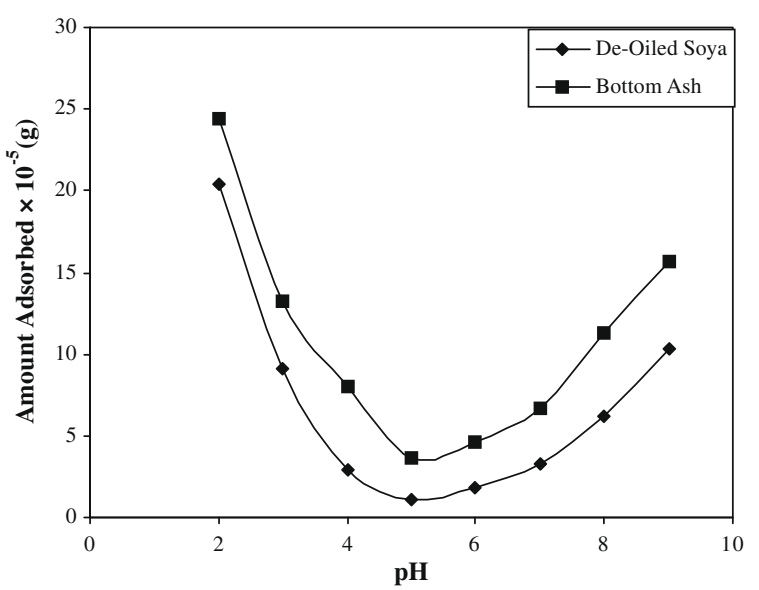

Fig. 1. Effect of $\mathrm{pH}$ on the uptake of phenol red by bottom ash and deoiled soya at $30{ }^{\circ} \mathrm{C}$ (bottom ash: concentration $=10 \times 10^{-5} \mathrm{M}$, adsorbent dose $=0.05 \mathrm{~g}$, particle size $=100$ BSS mesh) (deoiled soya: concentration $=10 \times 10^{-5} \mathrm{M}$, adsorbent dose $=0.05 \mathrm{~g}$, particle size $=36$ BSS mesh $)$.
Table 3

Effect of amount of adsorbents on the adsorption of phenol red (dye concentration $=10 \times 10^{-5} \mathrm{M}$ and $\mathrm{pH} 7.0$ ).

\begin{tabular}{|c|c|c|c|c|c|c|c|}
\hline \multirow[t]{2}{*}{$\begin{array}{l}\text { Amount of } \\
\text { bottom ash (g) }\end{array}$} & \multicolumn{3}{|c|}{$\begin{array}{l}\text { Amount } \\
\text { adsorbed } \times 10^{-5}(\mathrm{~g})\end{array}$} & \multirow[t]{2}{*}{$\begin{array}{l}\text { Amount of } \\
\text { deoiled soya }(\mathrm{g})\end{array}$} & \multicolumn{3}{|c|}{$\begin{array}{l}\text { Amount } \\
\text { adsorbed } \times 10^{-5}(\mathrm{~g})\end{array}$} \\
\hline & $30^{\circ} \mathrm{C}$ & $40^{\circ} \mathrm{C}$ & $50^{\circ} \mathrm{C}$ & & $30^{\circ} \mathrm{C}$ & $40^{\circ} \mathrm{C}$ & $50^{\circ} \mathrm{C}$ \\
\hline 0.1 & 43.5 & 46.6 & 49.3 & 0.1 & 15.9 & 28.4 & 43.3 \\
\hline 0.15 & 44.4 & 47.5 & 49.9 & 0.15 & 17.6 & 30.9 & 44.9 \\
\hline 0.2 & 45.1 & 48.1 & 50.6 & 0.2 & 19.0 & 32.2 & 46.0 \\
\hline 0.25 & 45.9 & 48.3 & 50.7 & 0.25 & 19.7 & 33.8 & 46.8 \\
\hline 0.3 & 46.6 & 48.8 & 51.1 & 0.3 & 22.1 & 35.3 & 47.6 \\
\hline
\end{tabular}

The decrease in the extent of adsorption with increase in $\mathrm{pH}$ value initially is due to the increased protonation by neutralization of negative charges at the surface of the adsorbents. For further studies $\mathrm{pH} 7$ was chosen, as this would give an idea of adsorption capacity in neutral conditions.

\subsubsection{Effect of amount of adsorbents}

In order to study the variation in adsorption on the basis of the amount of the adsorbent materials, various amounts ranging from 0.1 to $0.3 \mathrm{~g}$ for bottom ash and deoiled soya were taken in $100-\mathrm{ml}$ volumetric flasks having a dye solution of $10 \times 10^{-5} \mathrm{M}$ concentration and $\mathrm{pH}$ 7. The study was performed at three different temperatures $\left(30,40\right.$, and $\left.50^{\circ} \mathrm{C}\right)$. With increase in amount of adsorbent adsorption was found to increase (Table 3 ). Such a trend is mainly attributed to the fact that with increase in the amount of the adsorbent the adsorptive surface area increases which provides a greater number of active sites for adsorption [25]. It is interesting to note that the amount adsorbed also increased with elevation in temperature from 30 to $50{ }^{\circ} \mathrm{C}$.

\subsubsection{Effect of particle sizes}

Adsorption is further influenced by particle sizes. Three different particle sizes, viz. 36, 100, and 170 BSS mesh, were selected for batch adsorption studies for both adsorbents. The amount adsorbed increased with the increase in mesh size, which was found to be substantial for mesh size 170 BSS mesh, because the increased surface area of the adsorbent materials is due to smaller sizes (Table 4). This facilitates the accessibility of the adsorbent pores for diffusion of the dye, resulting in increased adsorption. The above result is further supported by the rate constant and half-life values obtained in each case.

\subsubsection{Effect of concentration}

A concentration range of $1 \times 10^{-5}$ to $10 \times 10^{-5} \mathrm{M}$ was selected and fixed amounts of the adsorbents were added to these solutions. It was found that with the increase in concentration of the dye adsorption increases at all temperatures $\left(30,40\right.$, and $\left.50^{\circ} \mathrm{C}\right)$ for both bottom ash and deoiled soya (Figs. 2 and 3). The figures also reveal that higher temperatures support a greater extent of adsorption. Greater temperature provides greater mobility to the

Table 4

Effect of sieve sizes of different adsorbents on the rate of adsorption of phenol red over bottom ash and deoiled soya (concentration $=10 \times 10^{-5} \mathrm{M}, \mathrm{pH} 7.0$, temperature $=30^{\circ} \mathrm{C}$, adsorbent dose $=0.1 \mathrm{~g}$ bottom ash and $0.1 \mathrm{~g}$ deoiled soya)

\begin{tabular}{|c|c|c|c|c|c|c|}
\hline \multirow{2}{*}{$\begin{array}{l}\text { Mesh } \\
\text { size }\end{array}$} & \multicolumn{3}{|l|}{ Bottom ash } & \multicolumn{3}{|c|}{ Deoiled soya } \\
\hline & $\begin{array}{l}\text { Amount } \\
\text { adsorbed } \\
\times 10^{-5}(\mathrm{~g})\end{array}$ & $k\left(\mathrm{~h}^{-1}\right)$ & $t_{1 / 2}(\mathrm{~h})$ & $\begin{array}{l}\text { Amount } \\
\text { adsorbed } \\
\times 10^{-5}(\mathrm{~g})\end{array}$ & $k\left(\mathrm{~h}^{-1}\right)$ & $t_{1 / 2}(\mathrm{~h})$ \\
\hline 36 & 39.8 & 0.02 & 27.8 & 15.9 & 0.01 & 83.8 \\
\hline 100 & 46.9 & 0.03 & 22.0 & 23.0 & 0.01 & 55.2 \\
\hline 170 & 54.0 & 0.04 & 17.7 & 28.3 & 0.02 & 43.1 \\
\hline
\end{tabular}




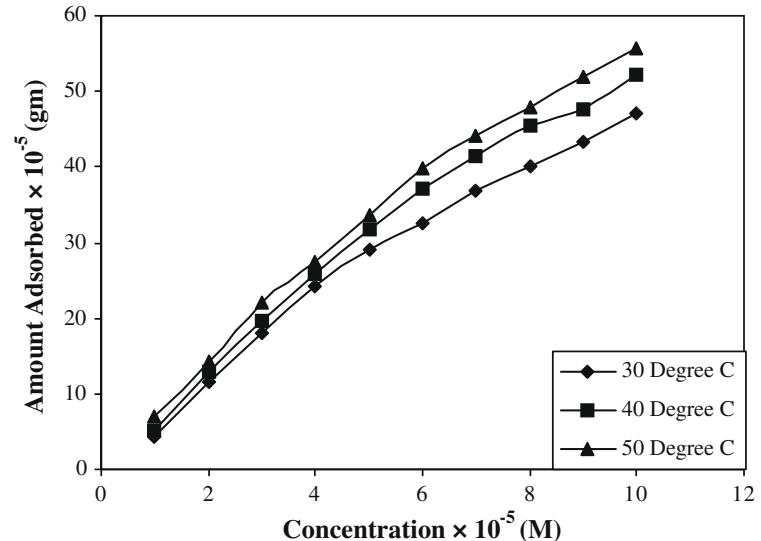

Fig. 2. Effect of concentration on the removal of phenol red by bottom ash at different temperatures (adsorbent dose $=0.1 \mathrm{~g}$, particle size $=100 \mathrm{BSS}$ mesh, pH 7.0).

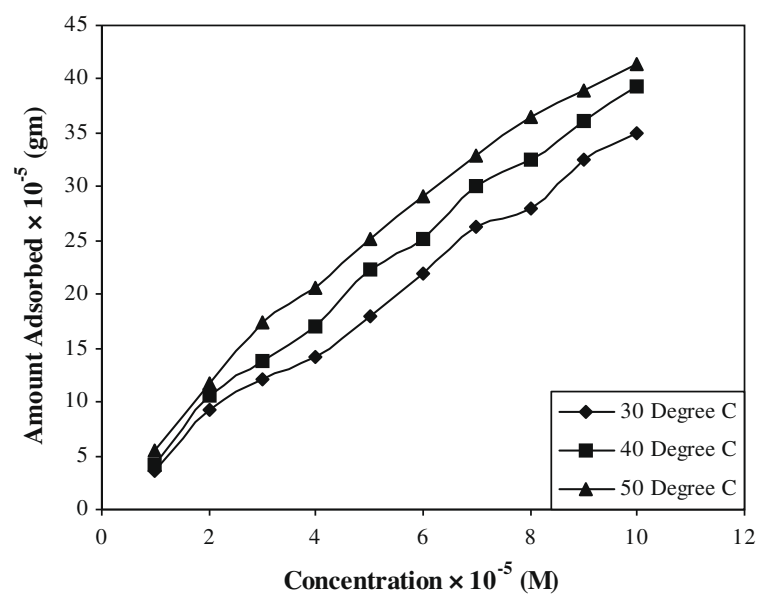

Fig. 3. Effect of concentration on the removal of phenol red by deoiled soya at different temperatures (adsorbent dose $=0.1 \mathrm{~g}$, particle size $=36$ BSS mesh, pH 7.0).

ionized dye molecules, thereby leading to greater adsorption. However, on increasing the concentration of the dye solution saturation of the adsorbent sites occurs which does not allow further adsorption of the dye molecules at all temperatures [26].

\subsubsection{Effect of contact time}

Contact time studies are helpful in understanding the amount of dye adsorbed at various time intervals by a fixed amount of the adsorbent ( $0.10 \mathrm{~g}$ for bottom ash and deoiled soya) at various temperatures 30,40 , and $50^{\circ} \mathrm{C}$. Figs. 4 and 5 clearly indicate that with increase in the time of contact and temperature, adsorption increases. The increase in adsorption with temperature indicates the endothermic nature of adsorption. After almost $4 \mathrm{~h}$ of contact, the percentage adsorption was $27.5 \%$ and $24.0 \%$ over bottom ash and deoiled soya, respectively. After this time no further increase in the adsorption is observed due to aggregation of the dye molecules at the adsorption sites on the adsorbents and increased diffusion path length [27]. The half-life value in both cases was calculated and was found to be 8.61 and $9.63 \mathrm{~h}$, respectively.

\subsection{Adsorption isotherms}

The adsorption of phenol red dye onto both adsorbents was studied at all three temperatures, viz. 30,40 , and $50^{\circ} \mathrm{C}$. The paper

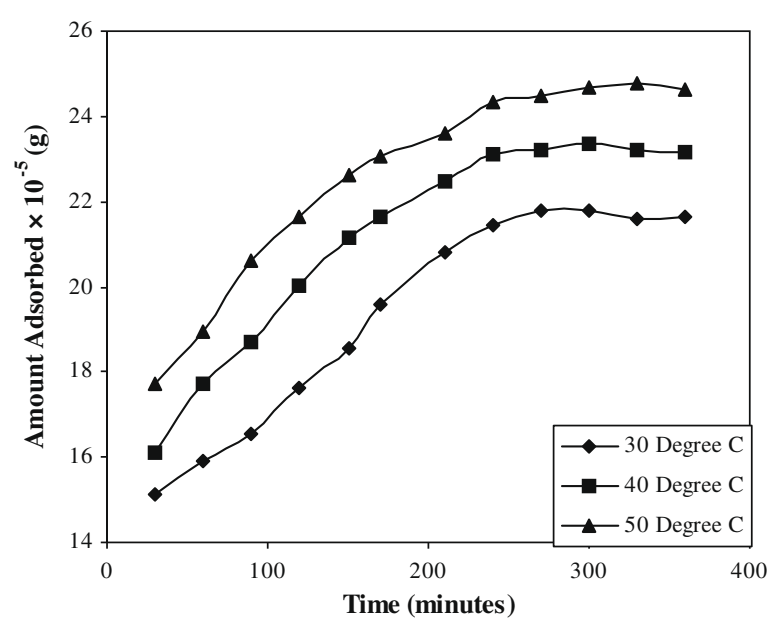

Fig. 4. Effect of contact time on the uptake of phenol red by bottom ash at different temperatures and at a concentration of $10 \times 10^{-5} \mathrm{M}$ (adsorbent dose $=0.1 \mathrm{~g}$, particle size $=100$ BSS mesh, $\mathrm{pH} 7.0$ ).

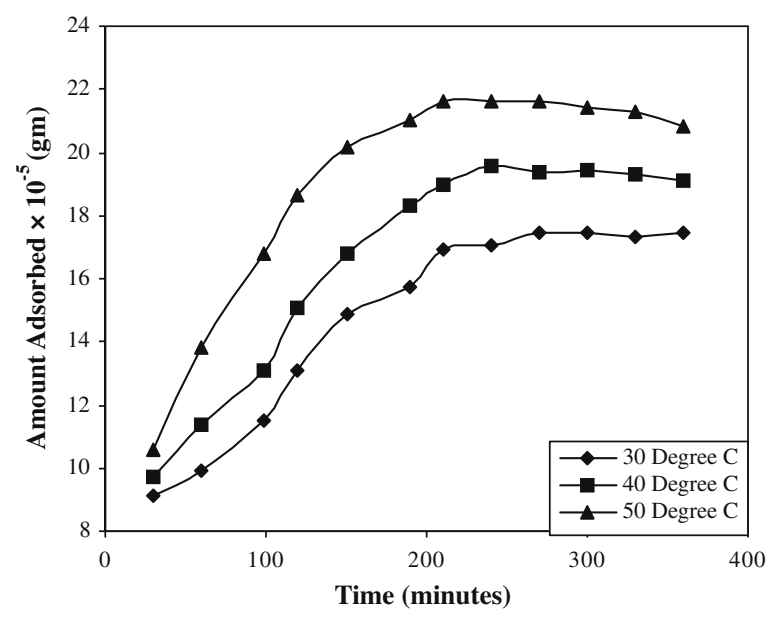

Fig. 5. Effect of contact time on the uptake of phenol red by deoiled soya at different temperatures and at a concentration of $10 \times 10^{-5} \mathrm{M}$ (adsorbent dose $=0.1 \mathrm{~g}$, particle size $=36$ BSS mesh, $\mathrm{pH} 7.0$ ).

deals mainly with four different kinds of isotherms, namely Langmuir, Freundlich, Tempkin, and $D-R$ isotherms.

\subsubsection{Langmuir isotherm}

The Langmuir isotherm assumes that the surface of any adsorbent material contains a number of active sites where the adsorbate attaches itself. This attachment can either be physical or chemical. When the attachment is via Van der Waal interactions it is known as physisorption and when via covalent bond it is known as chemisorption. It says that there is not much interaction between the adsorbate molecules and once a saturation value has been reached no further adsorption would take place [28-31].

$\frac{1}{q_{e}}=\frac{1}{Q_{0}}+\frac{1}{b Q_{0} C_{e}}$

where $q_{e}$ is the amount of phenol red adsorbed (mol/g), $C_{e}$ is the equilibrium molar concentration of the dye ( $\mathrm{mol} / \mathrm{L}), \mathrm{Q}_{0}$ is the maximum adsorption capacity ( $\mathrm{mol} / \mathrm{g})$, and $b$ is the energy of adsorption (L/mol).

A linear plot obtained for Langmuir isotherm is shown in Figs. 6 and 7. This isotherm holds good for the phenol red-bottom ash system and phenol red-deoiled soya system, which is indicated by the 


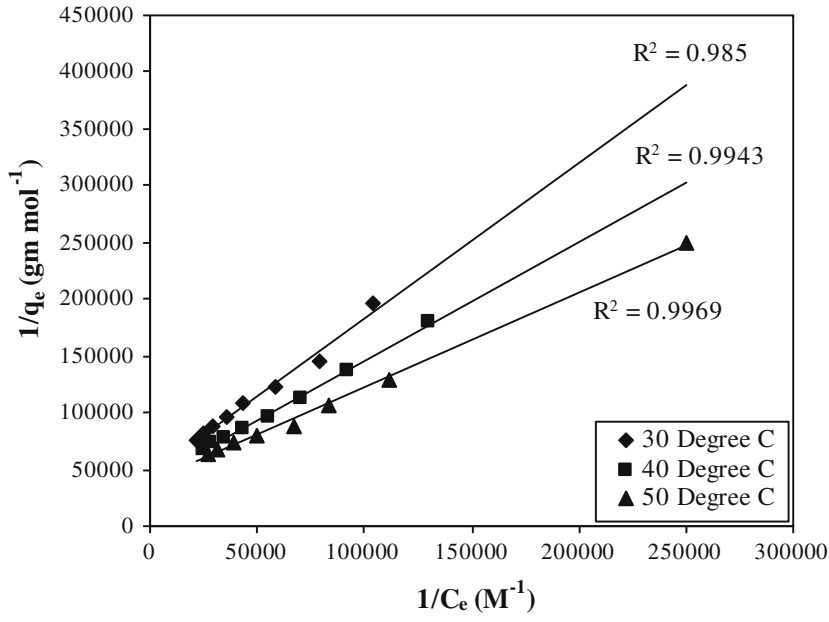

Fig. 6. Langmuir adsorption isotherms for the phenol red-bottom ash system (adsorbent dose $=0.1 \mathrm{~g}$, particle size $=100$ BSS mesh, pH 7.0).

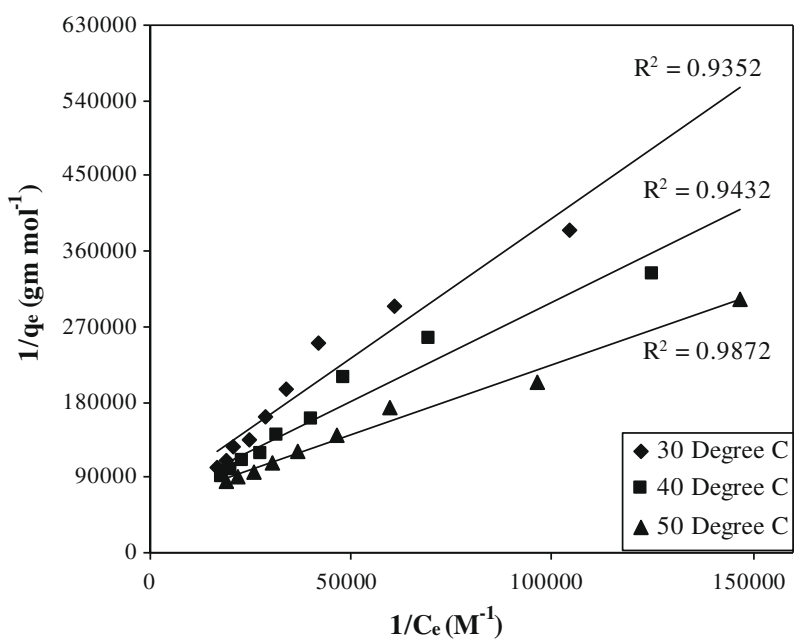

Fig. 7. Langmuir adsorption isotherms for the phenol red-deoiled soya system (adsorbent dose $=0.1 \mathrm{~g}$, particle size $=36$ BSS mesh, $\mathrm{pH} 7.0$ ).

linear plots obtained for $1 / q_{e}$ against $1 / C_{e}$, at each temperature. Various Langmuir constants have been calculated at 30,40, and $50{ }^{\circ} \mathrm{C}$ and depicted in Table 5 .

The essential feature of the Langmuir isotherm can be expressed by means of dimensionless constant separation factor, which is calculated using

\section{Table 5}

Freundlich and Langmuir constants for removal of phenol red (bottom ash: adsorbent dose $=0.1 \mathrm{~g}$, particle size $=100$ mesh, $\mathrm{pH} 7.0$; deoiled soya: adsorbent dose $=0.1 \mathrm{~g}$, particle size = 36 mesh, $\mathrm{pH} 7.0$ ).

\begin{tabular}{|c|c|c|c|c|c|c|}
\hline \multirow[t]{3}{*}{ Adsorbent } & \multicolumn{6}{|c|}{ Freundlich constants } \\
\hline & \multicolumn{3}{|l|}{$n$} & \multicolumn{3}{|l|}{$K_{F}$} \\
\hline & $30^{\circ} \mathrm{C}$ & $40^{\circ} \mathrm{C}$ & $50^{\circ} \mathrm{C}$ & $30^{\circ} \mathrm{C}$ & $40^{\circ} \mathrm{C}$ & $50^{\circ} \mathrm{C}$ \\
\hline Bottom ash & 1.5 & 1.5 & 1.5 & 0.01 & 0.01 & 0.02 \\
\hline \multirow[t]{3}{*}{ Deoiled soya } & 1.1 & 1.2 & 1.4 & 0.06 & 0.04 & 0.01 \\
\hline & \multicolumn{6}{|c|}{ Langmuir constants } \\
\hline & \multicolumn{3}{|c|}{$Q_{0} \times 10^{-5}(\mathrm{~mol} / \mathrm{g})$} & \multicolumn{3}{|c|}{$b \times 10^{4}(\mathrm{~L} / \mathrm{mol})$} \\
\hline Bottom ash & 2.1 & 2.4 & 2.6 & 3.4 & 3.9 & 4.6 \\
\hline Deoiled soya & 1.5 & 1.6 & 1.7 & 1.9 & 2.6 & 3.5 \\
\hline
\end{tabular}

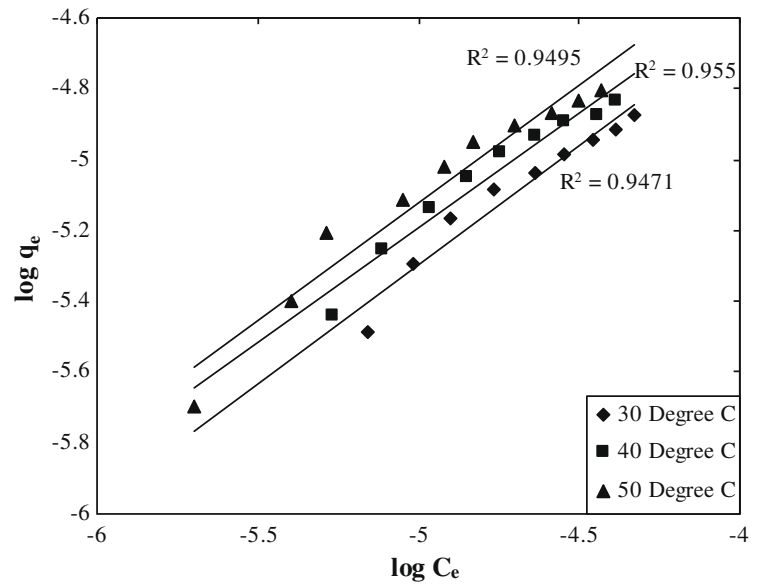

Fig. 8. Freundlich adsorption isotherms for the phenol red-bottom ash system (adsorbent dose $=0.1 \mathrm{~g}$, particle size $=100 \mathrm{BSS}$ mesh, $\mathrm{pH} 7.0$ ).

$r=\frac{1}{1+b C_{o}}$

where $b$ denotes the Langmuir constant and $C_{o}$ the initial concentration [32]. At all temperatures $r$ values have been found less than unity $(0.74,0.71$, and 0.68 for bottom ash and $0.33,0.27$, and 0.22 for deoiled soya) at 30,40 , and $50^{\circ} \mathrm{C}$, respectively, indicating thereby favorable processes for both adsorbents.

\subsubsection{Freundlich isotherm}

The Freundlich model $[33,34]$ is given by the relation

$\log q_{e}=\log K_{F}+\frac{1}{n} \log C_{e}$,

where $q_{e}$ is the amount adsorbed ( $\left.\mathrm{mol} / \mathrm{g}\right), C_{e}$ is the equilibrium concentration of the adsorbate $(\mathrm{mol} / \mathrm{L}) . K_{F}$ and $n$, the Freundlich constants, are related to adsorption capacity and adsorption intensity, respectively. The model is based on the assumption that adsorption occurs on a heterogeneous adsorption surface having unequally available sites with different energies of adsorption. Figs. 8 and 9 depict the plots obtained for the Freundlich isotherm for the two adsorbents along with their $R^{2}$ values. The Freundlich constants for both adsorbents were calculated and are presented in Table 5.

\subsubsection{Tempkin isotherm}

The Tempkin isotherm assumes that the heat of adsorption of all the molecules increase linearly with coverage [35]. The linear form of this isotherm can be given by

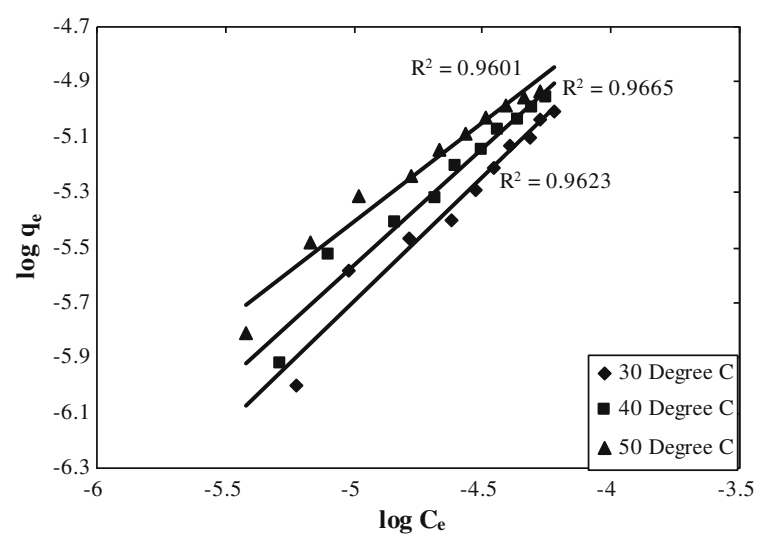

Fig. 9. Freundlich adsorption isotherms for the phenol red-deoiled soya system (adsorbent dose $=0.1 \mathrm{~g}$, particle size $=36$ BSS mesh, $\mathrm{pH} 7.0$ ). 


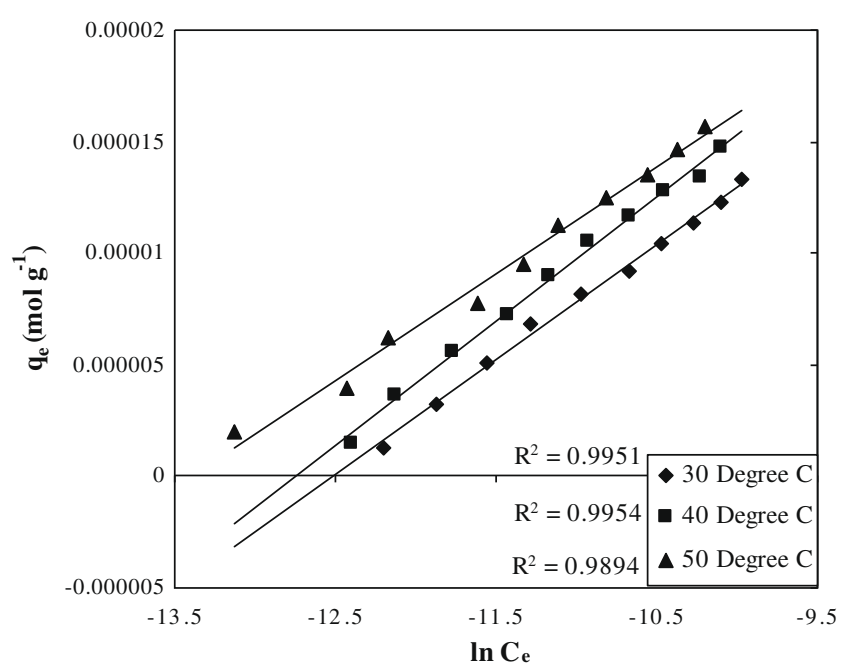

Fig. 10. Tempkin isotherms for the phenol red-bottom ash system at different temperatures.

$q_{e}=k_{1} \ln k_{2}+k_{1} \ln C_{e}$.

$q_{e}$ is the amount adsorbed at equilibrium in $\mathrm{mol} / \mathrm{gm}, k_{1}$ is the Tempkin isotherm energy constant in $\mathrm{L} / \mathrm{mol}$, and $k_{2}$ is the Tempkin isotherm constant. The slopes and intercepts obtained from the graphical plot (Figs. 10 and 11) were used to calculate the Tempkin constants (Tables 6 and 7).

\subsubsection{Dubinin-Radushkevich isotherm}

The linear form of the Dubinin-Radushkevich isotherm [36] can be given as

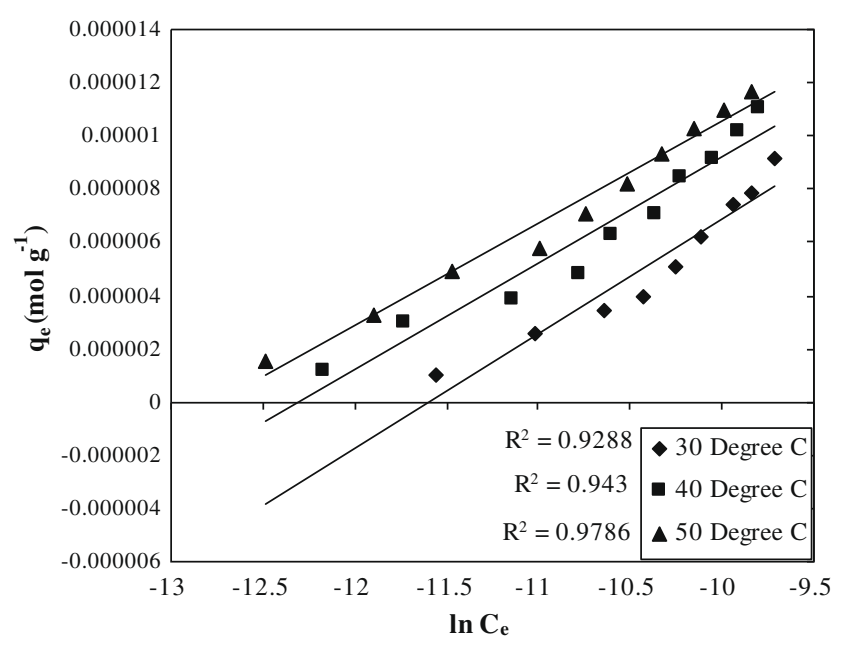

Fig. 11. Tempkin isotherms for the phenol red-deoiled soya system at different temperatures.

Table 6

Tempkin and $D-R$ constants for phenol red bottom ash system.

\begin{tabular}{lllll}
\hline Temperature $\left({ }^{\circ} \mathrm{C}\right)$ & Bottom ash & & \\
\cline { 2 - 5 } & Tempkin constant & \multicolumn{2}{l}{$D$-R constants } \\
\cline { 2 - 5 } & $k_{2}$ & $6\left(\mathrm{~mol}^{2} / \mathrm{J}^{2}\right)$ & $X_{m}(\mu \mathrm{mol} / \mathrm{g})$ & $E(\mathrm{~kJ} / \mathrm{mol})$ \\
\hline 30 & $1.6 \times 10^{5}$ & $6 \times 10^{-9}$ & 4.6 & 10.0 \\
40 & $1.6 \times 10^{5}$ & $4 \times 10^{-9}$ & 4.7 & 11.1 \\
50 & $1.6 \times 10^{5}$ & 4.8 & 11.1 \\
\hline
\end{tabular}

Table 7

Tempkin and $D-R$ constants for phenol red-deoiled soya system.

\begin{tabular}{|c|c|c|c|c|}
\hline \multirow[t]{3}{*}{ Temperature $\left({ }^{\circ} \mathrm{C}\right)$} & \multicolumn{4}{|l|}{ Deoiled soya } \\
\hline & \multirow{2}{*}{$\begin{array}{l}\text { Tempkin constant } \\
k_{2}\end{array}$} & \multicolumn{3}{|c|}{$D-R$ constants } \\
\hline & & $\beta\left(\mathrm{mol}^{2} / \mathrm{J}^{2}\right)$ & $X_{m}(\mu \mathrm{mol} / \mathrm{g})$ & $E(\mathrm{~kJ} / \mathrm{mol})$ \\
\hline 30 & $2.7 \times 10^{5}$ & $7 \times 10^{-9}$ & 5.8 & 8.5 \\
\hline 40 & $2.7 \times 10^{5}$ & $6 \times 10^{-9}$ & 5.1 & 9.1 \\
\hline 50 & $2.7 \times 10^{5}$ & $4 \times 10^{-9}$ & 4.6 & 11.2 \\
\hline
\end{tabular}

$\ln C_{a d s}=\ln X_{m}-\beta \varepsilon^{2}$,

where $\mathrm{C}_{a d s}$ is the amount of the dye adsorbed per unit weight of the adsorbent in $\mathrm{mg} / \mathrm{g}, X_{m}$ is the maximum sorption capacity provided by the intercept in $\mu \mathrm{mol} / \mathrm{g}, \beta\left(\mathrm{mol}^{2} / \mathrm{J}^{2}\right)$ is obtained from the slope of the straight-line plot of $\ln C_{a d s}$ versus $\varepsilon^{2}$ (Figs. 12 and 13), and $\varepsilon$, the Polanyi potential, can be calculated as

$\varepsilon=R T \ln \left(1+1 / C_{e}\right)$,

where $R$ is the universal gas constant in $\mathrm{kJ} /(\mathrm{mol} \mathrm{K})$ and $T$ is the temperature in Kelvin.

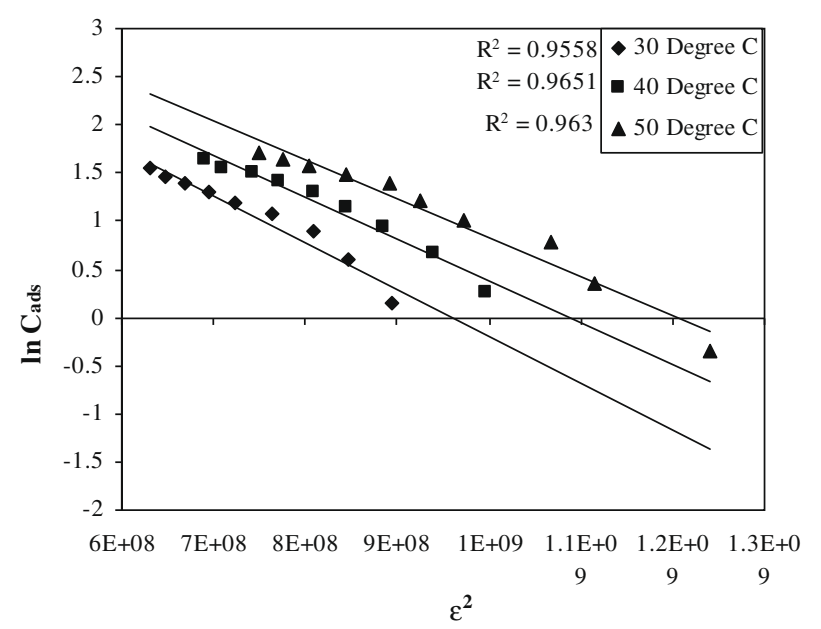

Fig. 12. $D-R$ isotherms for the phenol red-bottom ash system at different temperatures.

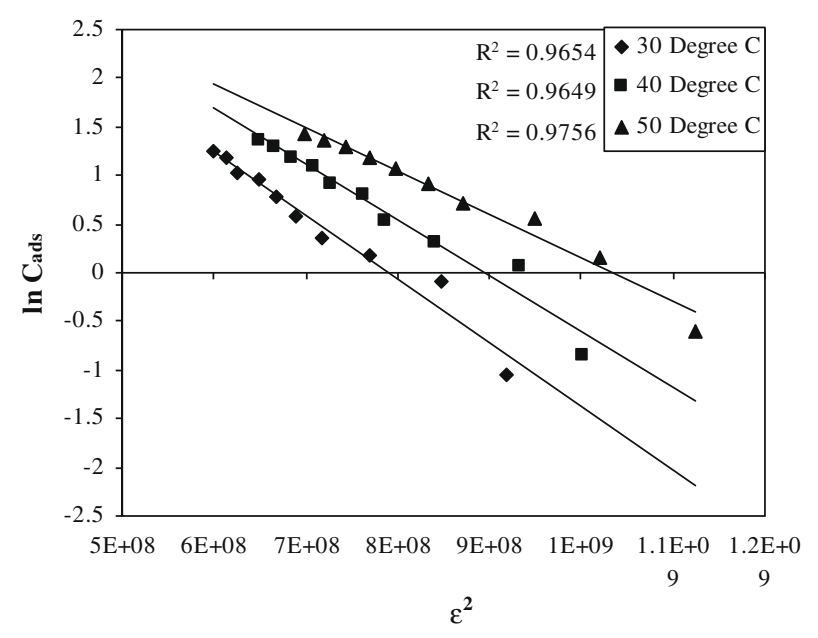

Fig. 13. $D-R$ isotherms for the phenol red-deoiled soya system at different temperatures. 
Table 8

Thermodynamic parameters for the uptake of phenol red (bottom ash: adsorbent dose $=0.1 \mathrm{~g}$, particle size $=100$ mesh, $\mathrm{pH} 7.0$; deoiled soya: adsorbent dose $=0.1 \mathrm{~g}$, particle size $=36$ mesh, $\mathrm{pH} 7.0$ ).

\begin{tabular}{|c|c|c|c|c|c|}
\hline \multirow[t]{2}{*}{ Adsorbent } & \multicolumn{3}{|c|}{$-\Delta G^{\circ} \times 10^{4}(\mathrm{~J} / \mathrm{mol})$} & \multirow[t]{2}{*}{$\Delta H^{\circ}(\mathrm{J} / \mathrm{mol})$} & \multirow[t]{2}{*}{$\Delta S^{\circ}(\mathrm{J} / \mathrm{K} / \mathrm{mol})$} \\
\hline & $30^{\circ} \mathrm{C}$ & $40^{\circ} \mathrm{C}$ & $50^{\circ} \mathrm{C}$ & & \\
\hline Bottom ash & 2.6 & 2.7 & 2.9 & 190.9 & 88.6 \\
\hline Deoiled soya & 2.5 & 2.6 & 2.8 & 373.1 & 85.9 \\
\hline
\end{tabular}

$E$, the mean sorption energy, is calculated using the following relation (Tables 6 and 7)

$E=(-2 K)^{-1 / 2}$.

The values of $E$ for both phenol red-bottom ash and phenol reddeoiled soya system are found to be in the range $8-11 \mathrm{~kJ} / \mathrm{mol}$. Thus, the calculated values of $E$ suggest that chemisorption is responsible for the adsorption process for both systems at all the temperatures [37].

\subsection{Calculation of thermodynamic parameters}

Gibb's free energy $\left(\Delta G^{\circ}\right)$, change in entropy $\left(\Delta S^{\circ}\right)$, and change in enthalpy $\left(\Delta H^{\circ}\right)$, etc. have been calculated from the following relations $[38,39]$ :

$\Delta G^{\circ}=-R T \ln b$,

$\Delta H^{\circ}=-R\left(\frac{T_{2} T_{1}}{T_{2}-T_{1}}\right) \times \ln \left(\frac{b_{2}}{b_{1}}\right)$,

$\Delta S^{\circ}=\frac{\Delta H^{\circ}-\Delta G^{\circ}}{T}$,

where $R$ is a universal gas constant, $b, b_{1}$, and $b_{2}$ are the Langmuir constants at 30,40 , and $50^{\circ} \mathrm{C}$, respectively, obtained from slopes and intercepts of Langmuir isotherms.

An increase in randomness is indicated by positive values of entropy change whereas the endothermic nature of the process is indicated by positive values of enthalpy. The feasibility of the process on the other hand is shown by negative values of free energy (Table 8).

\subsection{Rate constant study}

Pseudo-first-order and second-order rate equations were applied to phenol red-bottom ash system and phenol red-deoiled soya system $[40,41]$. The equations given below summarize the Lagergrens pseudo-first-order rate equation and pseudo-secondorder equation, respectively:

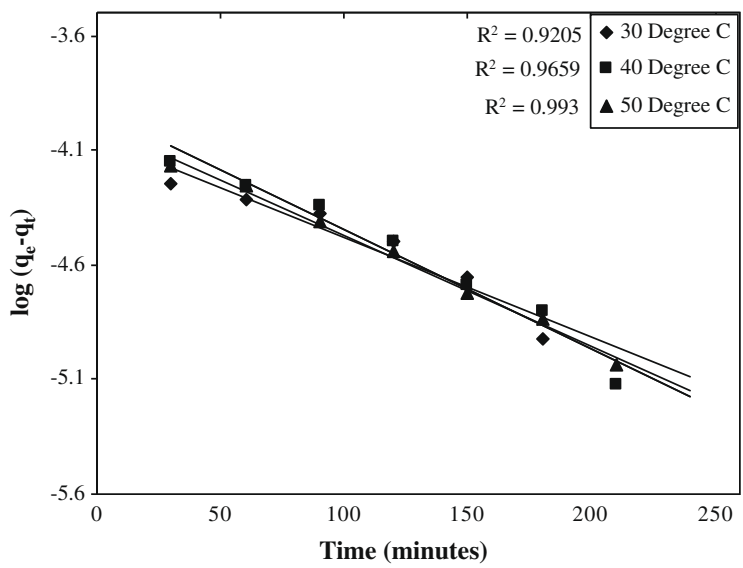

Fig. 14. Plot of $\log \left(q_{e}-q_{t}\right)$ versus time for the phenol red-bottom ash system at different temperatures.

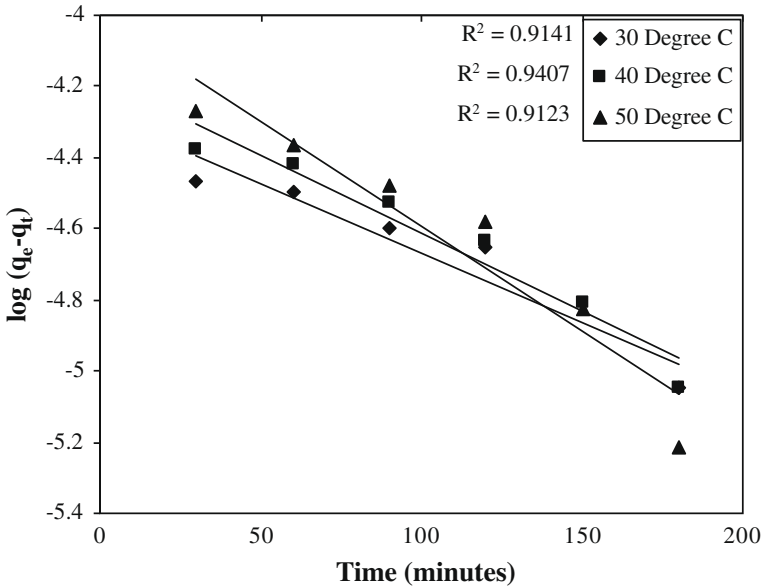

Fig. 15. Plot of $\log \left(q_{e}-q_{t}\right)$ versus time for the phenol red-deoiled soya system at different temperatures.

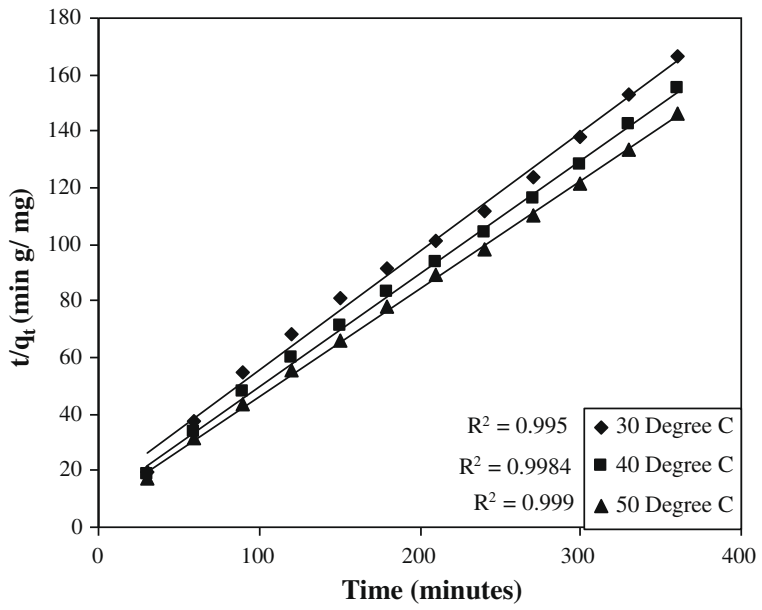

Fig. 16. Plot of time versus $t / q_{t}$ for the phenol red-bottom ash system at different temperatures.

$\log \left(q_{e}-q_{t}\right)=\log q_{e}-\frac{k_{a d}}{2.303} \times t$

$\frac{t}{q_{t}}=\frac{1}{k_{2} q_{e}^{2}}+\frac{t}{q_{e}}$

In the above equation $q_{e}$ and $q_{t}$ denote the amounts adsorbed at equilibrium and at any time $t$ in grams, respectively, and $k$ is a constant. In the case of pseudo-first-order a graph was plotted between $\log \left(q_{e}-q_{t}\right)$ versus time (Figs. 14 and 15), the slope of which gives the value of $k_{a d}$, whereas in the case of pseudo-second-order a graph was plotted between $t / q t$ versus time and in both cases straight-line graphs were obtained (Figs. 16 and 17). The $R^{2}$ values are indicative of the fact that the ongoing reaction proceeds via a pseudo-second-order mechanism rather than pseudo-first-order mechanism.

\subsection{Rate expression and treatment of the data}

For proper interpretation of the kinetic data, it is vital to identify the adsorption process steps, which govern the overall removal adsorption rate. The mathematical treatment recommended by Boyd et al. [42] was employed to differentiate between particle diffusion and film diffusion. Film diffusion occurs when the transport of adsorbate to the surface of the adsorbent takes place (external 


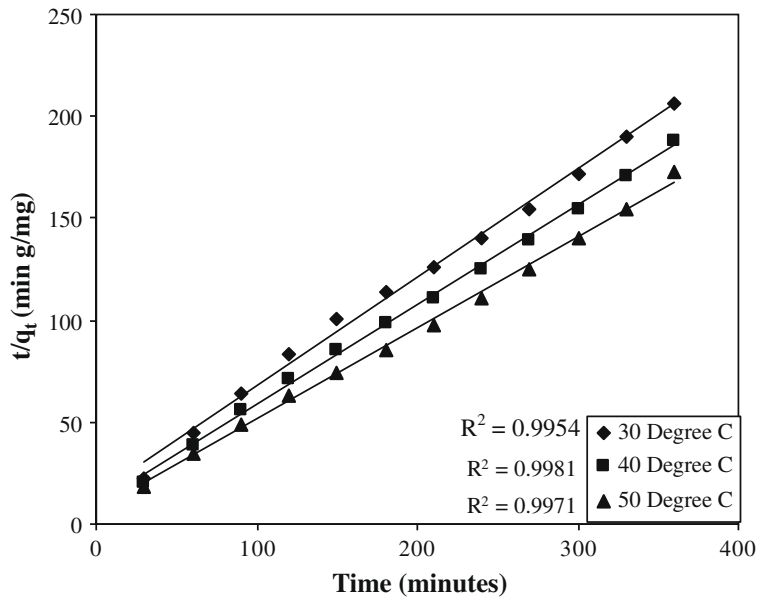

Fig. 17. Plot of time versus $t / q_{t}$ for the phenol red-deoiled soya system at different temperatures.

transport > internal transport) and particle diffusion when transport of the adsorbate within the pores of the adsorbent takes place (external transport < internal transport).

The fractional attainment $F$ of equilibrium at time t was calculated as follows:

$F=\frac{Q_{t}}{Q_{\infty}}$

Here $Q_{t}$ and $Q_{\infty}$ are amounts adsorbed after time $t$ and after infinite time, respectively.

The $F$ values were used to retrieve the $B_{t}$ values from the Reichenberg's table and a distinction between film diffusion and particle diffusion adsorption rate was made with the help of $B_{t}$ graphs obtained [43]. It is seen that the present adsorption process proceeds via particle diffusion at 30,40 , and $50^{\circ} \mathrm{C}$ for phenol redbottom ash system (Fig. 18) and at $50^{\circ} \mathrm{C}$ for phenol red-deoiled soya system whereas it proceeds via film diffusion at 30 and $40{ }^{\circ} \mathrm{C}$ for phenol red-deoiled soya system (Fig. 19). For both adsorbent materials the values of effective diffusion coefficient $D_{i}$ were calculated with the help of slopes of time versus $B_{t}$ graphs at 30,40 , and $50^{\circ} \mathrm{C}$.

$D_{i}=D_{o} \exp \left(-\frac{E_{a}}{R T}\right)$

$D_{o}=\left(2.72 d^{2} k T / h\right) \exp \left(\frac{\Delta S^{\#}}{R}\right)$.

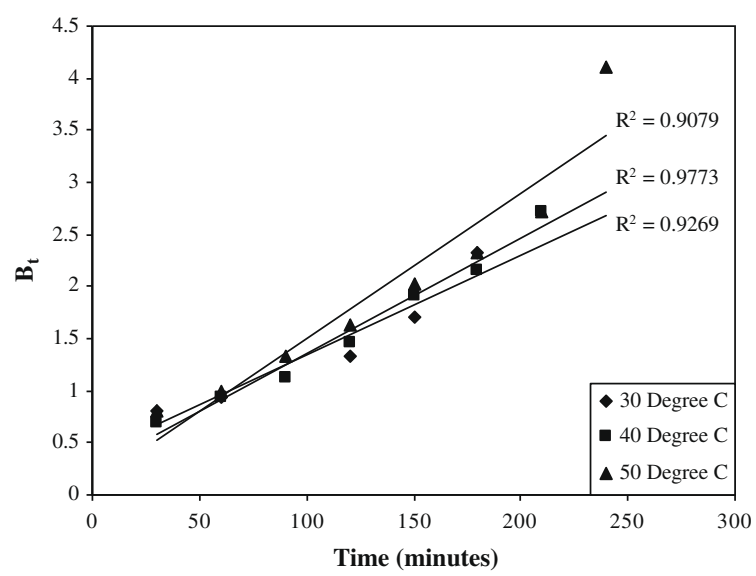

Fig. 18. Plot of time versus $B_{t}$ for the phenol red-bottom ash system at different temperatures.

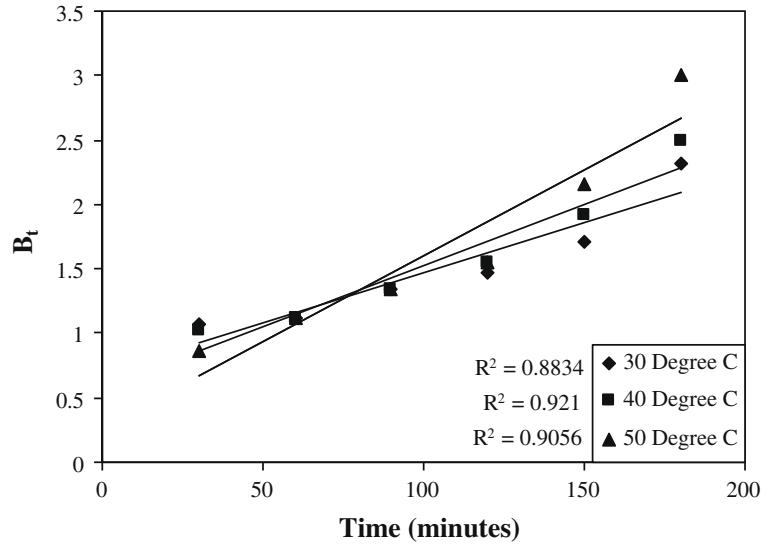

Fig. 19. Plot of time versus $B_{t}$ for the phenol red-deoiled soya system at different temperatures.

Table 9

Values of effective diffusion coefficient $\left(D_{i}\right)$, preexponential constant $\left(D_{o}\right)$, activation energy $\left(E_{a}\right)$, and entropy of activation $\left(\Delta S^{\#}\right)$ for the diffusion of phenol red adsorbing over bottom ash and deoiled soya.

\begin{tabular}{lllllll}
\hline Adsorbent & \multicolumn{1}{l}{$D_{i}$} & & & $D_{o}$ & $\begin{array}{l}E_{a} \\
(\mathrm{~J} / \mathrm{mol})\end{array}$ & $\begin{array}{l}-\Delta S^{\#} \\
(\mathrm{~J} / \mathrm{K} / \mathrm{mol})\end{array}$ \\
\cline { 2 - 4 } & $30{ }^{\circ} \mathrm{C}$ & $40{ }^{\circ} \mathrm{C}$ & $50{ }^{\circ} \mathrm{C}$ & & & \\
\hline Bottom ash & $5.1 \times 10^{-8}$ & $5.7 \times 10^{-8}$ & $8.0 \times 10^{-8}$ & $6 \times 10^{-5}$ & 17862.2 & 284.6 \\
Deoiled soya & $3.5 \times 10^{-7}$ & $4.3 \times 10^{-7}$ & $6.1 \times 10^{-7}$ & $3 \times 10^{-3}$ & 22819.5 & 252.1 \\
\hline
\end{tabular}

In the equations given above $D_{o}$ is the preexponential constant, $\Delta S^{\#}$ is the entropy, $d$ gives the average distance between two successive sites of the adsorbent, $h$ is Planks constant, $k$, Boltzmann constant, $E_{a}$, the energy of activation, $T$, the temperature, and $R$ is the universal gas constant. Table 9 shows the value obtained from these equations.

\subsection{Column studies}

Fixed-bed column studies were applied in order to observe the adsorptive tendency of the two adsorbent materials [44]. The adsorption process in fixed-bed columns appears to have a distinct advantage over batch-type operations due to the fact that in batchtype operations the effectiveness of the adsorbent material for removing solute from solution decreases as the adsorption proceeds, whereas in column operations the adsorbent is continuously in contact with solution of fixed concentration. As a result the exhaustion capacity of the column is relatively greater than that of batch capacity [45].

\subsubsection{Column adsorption}

Inlet flow rates, concentration, bed height, etc. were some of the factors playing a major role in column studies. A solution of concentration $10 \times 10^{-5} \mathrm{M}$ of the dye was passed through the columns at the rate of $0.5 \mathrm{ml} / \mathrm{min}$. The predicted breakthrough curves of eluted volume against concentration of eluted dye were sketched for the adsorption of dye over bottom ash and deoiled soya columns and are depicted in Fig. 20. It is found that bottom ash $(0.25 \mathrm{~g})$ adsorbs $0.84 \mathrm{mg}$ of the dye from $6.02 \mathrm{mg}$ of the dye present in the solution whereas on the other hand deoiled soya $(0.25 \mathrm{mg})$ adsorbs $0.74 \mathrm{mg}$ of the dye out of $2.83 \mathrm{mg}$ of it in the solution.

The equations below were used to calculate different parameters describing breakthrough curves: 


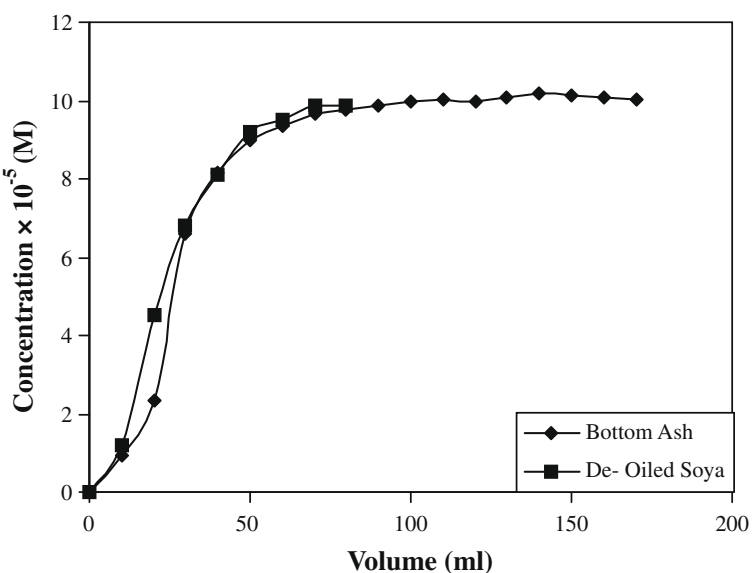

Fig. 20. Breakthrough curve for the phenol red-bottom ash and phenol red-deoiled soya columns.

$t_{x}=\frac{V_{x}}{F_{m}}$,

$t_{\delta}=\frac{V_{x}-V_{b}}{F_{m}}$,

$\frac{\delta}{D}=\frac{t_{\delta}}{t_{x}-t_{f}}=\frac{t_{\delta}}{t_{x}+t_{\delta}(f-1)}=\frac{\left(V_{x}-V_{b}\right)}{V_{b}+f\left(V_{x}-V_{b}\right)}$,

$f=1-\frac{t_{f}}{t_{\delta}}=\frac{M_{s}}{\left(V_{x}-V_{b}\right) C_{o}}$,

percentage saturation $=\frac{D+\delta(f-1)}{D} \times 100$.

Here, $\delta$ length of the primary adsorption zone, $t_{x}$, is the total time involved for the establishment of primary adsorption zone, $t_{\delta}$, time for the primary adsorption zone to move down its length, $t_{f}$, time for initial formation of primary adsorption zone, $F_{m}$, mass rate of flow of the adsorbent, and $f$ fractional capacity of the column. Tables 10 and 11 portray the values calculated for all these parameters. The mass flow rate calculated in case of both adsorbent materials is found to be $2.25 \times 10^{-5} \mathrm{mg} / \mathrm{cm}^{2} / \mathrm{min}$ for bottom ash and $2.25 \times 10^{-2} \mathrm{mg} / \mathrm{cm}^{2} / \mathrm{min}$ for deoiled soya. The total time involved for the establishment of primary adsorption zone $\left(t_{x}\right)$ and the time for the primary adsorption zone to move down its length $\left(t_{\delta}\right)$ were found to be $5.75 \times 10^{6}$ and $4.87 \times 10^{6} \mathrm{~min}$ for bottom ash and $2.6 \times 10^{3}$ and $2.2 \times 10^{3}$ min for deoiled soya, respectively. A greater set of values for $t_{x}$ and $t_{\delta}$ is obtained for the phenol red-bottom ash system than the phenol red-deoiled soya system.

Table 10

Fixed-bed adsorber calculations.

\begin{tabular}{clllllll}
\hline Adsorbent $\begin{array}{l}C_{o} \\
(\mathrm{M})\end{array}$ & $\begin{array}{l}C_{x} \\
(\mathrm{M})\end{array}$ & $\begin{array}{l}C_{b} \\
(\mathrm{M})\end{array}$ & $\begin{array}{l}V_{x} \\
(\mathrm{ml})\end{array}$ & $\begin{array}{l}V_{b} \\
(\mathrm{ml})\end{array}$ & $\begin{array}{l}\left(V_{x}-V_{b}\right) \\
(\mathrm{ml})\end{array}$ & $\begin{array}{l}F_{m} \\
\left(\mathrm{mg} / \mathrm{cm}^{2} /\right. \\
\mathrm{min})\end{array}$ & $\begin{array}{l}D \\
(\mathrm{~cm})\end{array}$ \\
\hline $\begin{array}{c}\text { Bottom } \\
\text { ash } \\
\begin{array}{c}\text { Deoiled } \\
\text { soya }\end{array}\end{array}$ & $10 \times 10^{-5} 9.7 \times 10^{-5}$ & $1.1 \times 10^{-5}$ & 130 & 20 & 110 & $2.2 \times 10^{-5}$ & 0.5 \\
\hline
\end{tabular}

Table 11

Parameters for fixed-bed adsorber.

\begin{tabular}{lllllll}
\hline Adsorbent & $t_{x}(\mathrm{~min})$ & $t_{\delta}(\mathrm{min})$ & $t_{f}(\mathrm{~min})$ & $f$ & $\delta(\mathrm{cm})$ & $\begin{array}{l}\text { Percentage } \\
\text { saturation }\end{array}$ \\
\hline Bottom ash & $5.7 \times 10^{6}$ & $4.8 \times 10^{6}$ & 40 & 1.0 & 0.4 & 99.1 \\
Deoiled soya & $2.6 \times 10^{3}$ & $2.2 \times 10^{3}$ & 20 & 1.0 & 0.4 & 99.1 \\
\hline
\end{tabular}

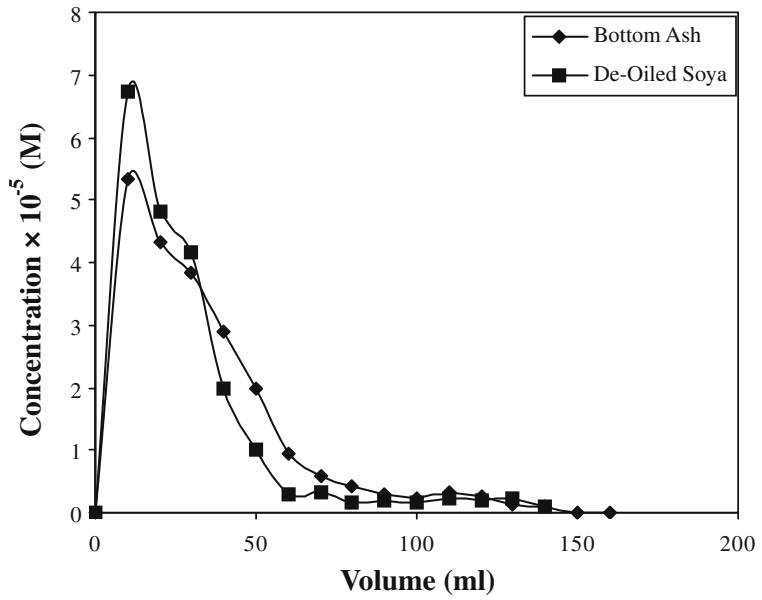

Fig. 21. Desorption of phenol red from bottom ash and deoiled soya columns.

\subsubsection{Column regeneration and dye recovery}

Acidic water $(\mathrm{pH} 2)$ was used for the eluting of columns of both adsorbents. The flow rate in both cases was maintained at $0.5 \mathrm{ml} /$ $\mathrm{min}$. The curves for desorption obtained for the two adsorbents are shown in Fig. 21. Complete desorption of the dye was achieved by using $140 \mathrm{ml}$ of acidic water in both cases. In the case of bottom ash and deoiled soya the percentage recovery of the dye was $91.4 \%$ and $98.2 \%$, respectively.

Out of the $8.42 \times 10^{-4} \mathrm{~g}$ of the dye adsorbed $84 \%$ of the dye was removed in the case of bottom ash whereas out of $7.42 \times 10^{-4} \mathrm{~g}$ of the dye adsorbed $92 \%$ is removed in the case of deoiled soya, for the first $70 \mathrm{ml}$. The rest of the $70 \mathrm{ml}$ of the eluent was sufficient to remove almost all of the adsorbed dye from both columns.

After the desorption process both columns were washed with hot water at a flow rate of $0.5 \mathrm{ml} / \mathrm{min}$. The columns were loaded with the dye solution of known concentration and then desorption was carried out several times to obtain the breakthrough capacities of the columns. The breakthrough capacities during the first, second, third, and fourth cycles were found to be $72,50,44$, and $48 \mathrm{mg} / \mathrm{g}$ for bottom ash column and $70,63,55$, and $40 \mathrm{mg} / \mathrm{g}$ for the deoiled soya column.

\section{Conclusions}

The foregoing experiments reveal that bottom ash and deoiled soya prove to be efficient adsorbents for the removal of phenol red dye from wastewaters. These adsorbent materials are cheap and easily available with high potential of adsorbing the dye from wastewaters than the commercially available materials. Maximum monolayer capacity was observed at higher temperatures for both adsorbents. The negative values of $\Delta G^{\circ}$ indicate the spontaneity whereas the positive values of $\Delta H^{\circ}$ and $\Delta S^{\circ}$ indicate the endothermic nature and increase in randomness of the process taking place, respectively. The activation energies for the phenol red-bottom ash and phenol red-deoiled soya system were found to be 1.78 and $2.28 \mathrm{~K} \mathrm{~J} / \mathrm{mol}$, respectively. The process was concluded to proceed by a pseudo-second-order mechanism. The percentage recovery greater than $90 \%$ for both adsorbents proved their effectiveness. Hence from the above discussion the fact has been established that bottom ash and deoiled soya can be used effectively as adsorbents for the removal and recovery of phenol red from wastewaters.

\section{Acknowledgments}

Authors Dipika Kaur and Arti Malviya are thankful to MHRD, New Delhi, for providing fellowship under Technical Education Quality Improvement Program (TEQIP) of Govt. of India. 


\section{References}

[1] S. Pirillo, M.L. Ferreira, E.H. Rueda, Ind. Eng. Chem. Res. 46 (2007) 8255.

[2] G. Mishra, M. Tripathy, Colourage 40 (1993) 35.

[3] U.M. Pagga, K. Taeger, Water Resource Res. 28 (1994) 1051.

[4] W. Chu, C.W. Ma, Water Res. 34 (2000) 3153.

[5] A.T. Peter, H.S. Freeman, Physico-Chemical Principles of Color Chemistry, Blackie Academic and Professional, London, 1996.

[6] O. Tunay, I. Kabdasli, G. Eremektar, D. Orhon, Water Sci. Technol. 34 (1996) 9.

[7] G. Annadurai, R.S. Juang, D.J. Lee, J. Hazard. Mater. 92 (2002) 263.

[8] S. Senthilkumaar, P. Kalaamani, C.V. Subburaam, J. Hazard. Mater. 136 (2006) 800.

[9] R. Hana, Y. Wang, P. Hana, J. Shi, J. Yang, Y. Lub, J. Hazard. Mater. 137 (2006) 550.

[10] S.K. Srivastava, V.K. Gupta, D. Mohan, J. Environ. Eng. (ASCE) 123 (1997) 461.

[11] V.K. Gupta, K.T. Park, S. Sharma, D. Mohan, Environmentalist 19 (1998) 129.

[12] <http://en.wikipedia.org/wiki/phenol_red>.

[13] M.M. Walsh-Reitz, F.G. Toback, Am. J. Physiol.-Renal Phys. 262 (1992) F687.

[14] <http://www.glue.umd.edu/ choi/MSDS/Sigma-Aldrich/PHENOL\%20RED.pdf>.

[15] S.M. Baylor, S. Hollingworth, J. Gen. Physiol. 96 (1990) 449.

[16] K. Chung, G.E. Fulk, A.W. Andrews, Appl. Environ. Microbiol. 42 (1981) 641

[17] S.V. RamaRao, A.K. Panda, M.V.L.N.G. Raju, S. Sunder, N.K. Praharaj, Anim. Feed Sci. Technol. 106 (2003) 199.

[18] A. Mittal, D. Kaur, J. Mittal, J. Hazard. Mater. 163 (2009) 568.

[19] A. Mittal, D. Kaur, J. Mittal, J. Colloid Interface Sci. 326 (2008) 8.

[20] A. Mittal, V.K. Gupta, A. Malviya, J. Mittal, J. Hazard. Mater. 151 (2008) 821.

[21] A. Mittal, A. Malviya, D. Kaur, J. Mittal, L. Kurup, J. Hazard. Mater. 148(2007) 229.
[22] A. Mittal, J. Mittal, L. Kurup, A.K. Singh, J. Hazard. Mater. 38 (2006) 95

[23] A. Mittal, J. Mittal, L. Kurup, J. Hazard. Mater. 136 (2006) 567.

[24] V.K. Gupta, A. Mittal, V. Gajbe, J. Mittal, Ind. Eng. Chem. Res. 45 (2006) 1446

[25] H. Lata, V.K. Garg, R.K. Gupta, Dyes Pigm. 74 (2007) 653.

[26] V.K. Garg, R. Kumar, R. Gupta, Dyes Pigm. 62 (2004) 1.

[27] V.K. Gupta, I. Ali, X. Suhas, D. Mohan, J. Colloid Interface Sci. 265 (2003) 257

[28] I. Langmuir, J. Am. Chem. Soc. 38 (1916) 2221.

[29] Y. Satyawali, M. Balakrishnan, Biores. Technol. 98 (2007) 2629.

[30] B.H. Hameed, A.A. Ahmad, N. Aziz, Chem. Eng. J. 133 (2007) 195.

[31] M.T. Sulak, E. Demirbas, M. Kobya, Biores. Technol. 98 (2007) 2590.

[32] T.M. Weber, R.K. Chakrabarti, Am. Inst. Chem. Eng. J. 20 (1974) 228.

[33] N.G. Chilton, J.N. Losso, W.E. Marshall, R.M. Rao, Biores. Technol. 85 (2002) 131.

[34] J.F. Osma, V. Saravia, J.L. Toca-Herrera, S.R. Couto, J. Hazard. Mater. 147 (2007) 900.

[35] S.J. Allen, G. Mckay, J.F. Porter, J. Colloid Interface Sci. 280 (2004) 322.

[36] T.V.N. Padmesh, K. Vijayaraghavan, G. Sekaran, M. Velan, Bioremediation J. 10 (2006) 37.

37] Y.S. Ho, J.F. Porter, G. McKay, Water Air Soil Pollut. 141 (2002) 1.

[38] J. Wu, H. Yu, J. Hazard. Mater. 137 (2006) 498.

[39] T.K. Kim, Y.A. Son, Y.J. Lim, Dyes Pigm. 72 (2007) 246.

[40] Y. Bulut, N. Gozubenli, H. Aydyn, J. Hazard. Mater. 144 (2007) 300.

[41] G. Crini, H.N. Peindy, F. Gimbert, C. Robert, Sep. Purif. Technol. 53 (2007) 97.

[42] G.E. Boyd, A.W. Adamson, L.S. Meyers, J. Am. Chem. Soc. 69 (1947) 2836.

[43] G.S. Gupta, G. Prasad, V.N. Singh, Water Res. 24 (1990) 45.

[44] A.A. Attia, B.S. Girgis, N.A. Fathy, Dyes Pigm. 76 (2008) 282.

[45] A. Adak, M. Bandyopadhyay, A. Pal, Dyes Pigm. 69 (2006) 245. 